\title{
JAWABAN SOAL UTS 2018/2019 MATAKULIAH PRAKTEK PEMROGRAMAN DELPHI
}

\section{ARIEF DARMAWAN} 155100007

Fakultas Komputer, 4487572-45

Ariefdarmawan.student@umitra.ac.id

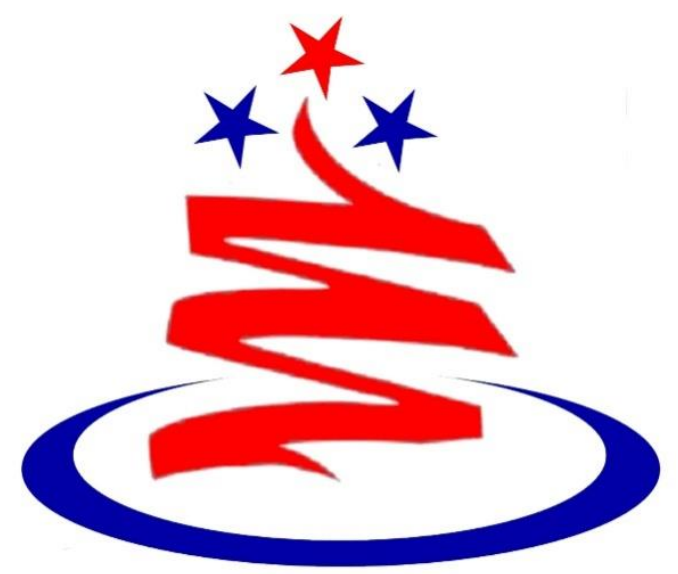

UnIVERSITAS mITRA InDONESIA 
A. STUDI KASUS ( SK )

Pertanyaan Type B :

Paparkan dan jelaskan logo anda!

Jawaban :

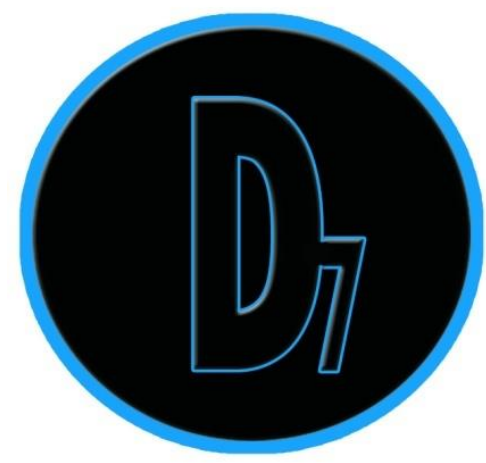

D7, adalah sebuah logo yang saya rancang yang berarti delphi7, logo ini saya buat untuk latar gambar dari program yang saya buat yaitu menggunakan Delphi7.

Arti logo :

a. Bulat atau lingkaran, maksudnya adalah seperti kita ketahui bahwa sebuah lingkaran tidak mempunyai titik ujungnya, dengan demikian maksudnya adalah program atau desain yang saya buat ini diharapkan akan selalu menguntungkan dan tidak mempunyai ujungnya.

b. D7, adalah nama dari program yang saya buat yaitu mengggunakan delphi7.

c. Warna latar hitam, menandakan kekuatan, elegan, kemewahn dan sebuah formalitas.

d. Warna biru, merupakan simbol ketenangan, keyakinan, keseriusan dan kepercayaan.

\section{B. STUDI REFERENSI ( SP )}

Pertanyaan Jenis A :

Jelaskan fungsi-fungsi detail dalam object inspector!

Jawaban :

Berikut adalah gambar object inspector.

\begin{tabular}{|c|c|c|}
\hline \multicolumn{2}{|l|}{ Object Inspector } & $x$ \\
\hline Form1 & TForm1 & 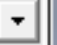 \\
\hline \multicolumn{3}{|c|}{ Properties |Events $\mid$} \\
\hline Action & & A \\
\hline ActiveControl & & \\
\hline Align & alNone & \\
\hline AlphaBlend & False & \\
\hline AlphaBlendValt & 255 & \\
\hline ĐAnchors & [akLeft,akTop & \\
\hline AutoScroll & True & \\
\hline AutoSize & False & \\
\hline BiDillode & bdLeftT oRighl & \\
\hline ĐBorderlcons & [biSystemMen & \\
\hline BorderStyle & bsSizeable & \\
\hline Borderwidth & 0 & \\
\hline Caption & Form1 & \\
\hline ClientHeight & 442 & \\
\hline Clientwidth & 708 & \\
\hline Color & $\square$ clBtnFacı & $\rightarrow$ \\
\hline All shown & & $/ 1 /$ \\
\hline
\end{tabular}

Secara Umum Object Inspector terbagi menadi 2, yaitu : 
a. Properties, Digunakan untuk mengatur tampilan pada sebuah komponen baik itu meliputi penggantian nama, warna, jenis huruf, border dan lain lain.

Contoh : Action, Activecontrol, Align, Alphablend, Alphablendvalue, Anchors, Dll

b. Events Merupakan jendela properties yang digunakan untuk memberikan fungsi yang lebih detail dari fungsi sebenarnya. Misalnya ketika tombol Simpan di klik maka program akan menjalankan perintah penyimpanan data. Dari kalimat tersebut ada event clik untuk mengeksekusi sebuah tombol simpan. Perintah event clik tersebut dapat diberikan melalui jendela events.

Contoh : Action, Activecontrol, Menu, Onactive, Dll.

\section{STUDI PENALARAN ( SP )}

Pertanyaan Kategori 2 :

Buatlah aplikasi SEGITIGA.

Jawaban :
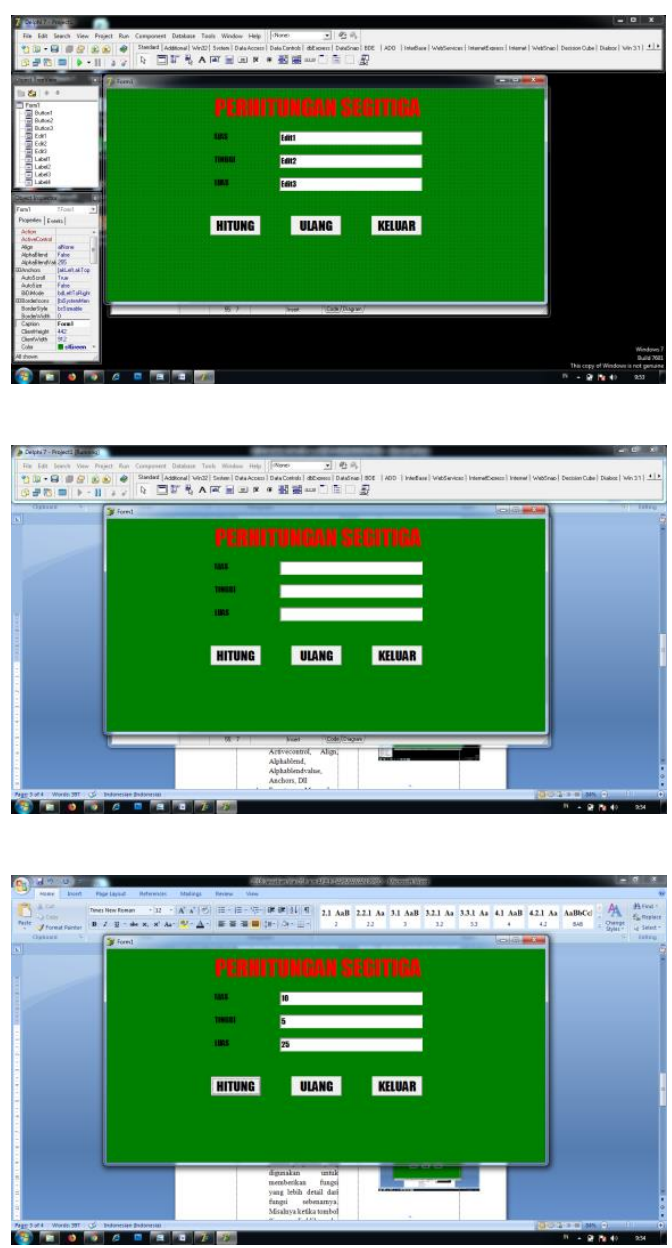

D. REFERENSI

[1] A. S. Putra And O. M. Febriani, "Knowledge Management Online Application In Pdam Lampung Province," In Prosiding International Conference On Information 
Technology And Business

(Icitb), 2018, Pp. 181-187.

[2] A. S. Putra, O. M. Febriani, And

B. Bachry, "Implementasi

Genetic Fuzzy System Untuk

Mengidentifikasi Hasil Curian

Kendaraan Bermotor Di Polda

Lampung," J. Sist. Inf. Dan

Manaj. Basis Data, Vol. 1, No.

1, Pp. 21-30, 2018.

[3] O. M. Febriani And A. S. Putra, "Sistem Informasi Monitoring Inventori Barang Pada Balai Riset Standardisasi Industri Bandar Lampung," J. Inform., Vol. 13, No. 1, Pp. 90-98, 2014.

[4] Putra, Arie Setya. "2018 Artikel Struktur Data, Audit Dan Jaringan Komputer." (2018).

[5] Putra, A. S. (2018, July 17). Paperplain Fundamental Create Application With Borland Delphi 7.0 University Of Mitra Indonesia. Retrieved From Osf.Io/Pbrn9. 